\title{
Three new species of Scythrididae from the northern Tien-Shan Mountains (Lepidoptera: Scythrididae)
}

\author{
Kari Nupponen \& Sergey Yu. Sinev
}

\begin{abstract}
Nupponen, K. \& Sinev, S. Yu. 2011: Three new species of Scythrididae from the northern Tien-Shan Mountains (Lepidoptera: Scythrididae). — Entomol. Fennica 22: 121-128.

Three new species of the family Scythrididae are described from Central Asian mountains: Scythris cultelloides Nupponen \& Sinev, sp. n., S. danilevskyi Nupponen \& Sinev, sp. n. and $S$. ganesha Nupponen \& Sinev, sp. n. One unknown species is reported but not formally described because only a single female is available.

K. Nupponen, Merenneidontie 19 D, FI-02320 Espoo, Finland; E-mail: Kari.Nupponen@kolumbus.fi

S. Yu. Sinev, Zoological Institute, Russian Academy of Sciences, Universitetskaja nab. 1, RU-1999034 St. Petersburg, Russia; E-mail: lepid@zin.ru
\end{abstract}

Received 11 December 2010, accepted 10 January 2011

\section{Introduction}

The Tien-Shan Mountains are one of the main great mountain chains in Central Asia. It is lying mainly in Kyrgyzstan and northwestern China (Xinjiang district), and its ranges and valleys stretch for about 2,500 km in an east-west direction.

The highest point of the Tien-Shan Mountains is the Victory Peak (Pik Pobeda, 7,439 m) in Kyrgyzstan. The mountain chain is divided into subregions, of which the Northern Tien-Shan includes the Semirechiy area of Kazakhstan and Northern Kyrgyzstan, which consists mainly of Zailiyskiy [Transili] Alatau, Kungei Ala-Too, Terskei Ala-Too and Kyrgyz Ala-Too ranges.

The scythridid fauna of the Tien-Shan Mountains is almost completely unknown. A few species have been described from its northern foothills in Kazakhstan (Bengtsson 1997, Nupponen et al.2005). However, there is so far no published data on Scythrididae at high altitudes of the Tien-
Shan range, although a few occasionally collected specimens are known to exist in museum collections.

\section{Material}

The present article is based on material collected by L. Huldén, L. Kaila and K. Mikkola during a Finnish-Russian expedition to the Northern TienShan range in 1990, and a few specimens from the same region, which were collected by A. S. Danilevsky and V. I. Kuznetsov in 1957 and preserved in ZISP. Some specimens collected during a Finnish-Estonian expedition to Kyrgyzstan in 2010 are included in the type series too, but main part of the results of that trip will be reported in a separate article (Nupponen in prep.).

The following abbreviations are used in the species list: MZH (Finnish Museum of Natural History, University of Helsinki, Finland), ZISP (Zoological Institute, St. Petersburg, Russia). 


\section{Descriptions of new species}

\subsection{Scythris cultelloides \\ Nupponen \& Sinev, sp. n.}

Type material. Holotype: $\widehat{\jmath}$ (Fig. 1): Kyrgyzstan, Alai mts., $39^{\circ} 49^{\prime} 51.6^{\prime \prime} \mathrm{N} \mathrm{73} 3^{\circ} 16^{\prime} 15.4^{\prime \prime} \mathrm{E}$, Pamirsky trakt, near Ak-Bosogo village, $2,725 \mathrm{~m}$ a.s.1., 01.VIII.2010, K. Nupponen leg. In coll. $\mathrm{MZH}$.

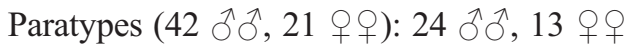
same data as holotype; Kyrgyzstan, Trans-Alai mts., 39³9' 49.9' N 73 52'01.1' E, Nura River, SW from Irkeshtam village, 2,930 $\mathrm{m}$ a.s.1., 30.VII.2010, 11 ふึે, 6 우, K. Nupponen leg., 1 ๙ิ, 1 ㅇ, A. Pototski leg., 2 ふ઼ A. \& A. Selin leg.;

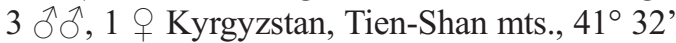
13.2" N 76 28' 39.4" E, Eki-Naryn, 2,500 m a.s.1., 05.VIII.2010, K. Nupponen leg.; $1 \hat{\sigma}$ Kyrgyzstan, $41^{\circ} 25^{\prime} \mathrm{N} 76^{\circ} 20^{\prime} \mathrm{E}, 30 \mathrm{~km}$ E Naryn, 2,500 m a.s.1., steppe slope, 29.VII.1990, L. Kaila \& K. Mikkola leg. Genitalia slides: K. Nupponen prep. no. 3/13.I.2010 (ふ), 2/20.XI.2010 (す), 3/20.XI.2010 (†). In colls. T. \& K. Nupponen and MZH.

Diagnosis. Externally S. cultelloides Nupponen \& Sinev, sp. n. may be confused with many small dark scythridids. Narrow pale brown forewings may help to identify the moth, but examination of the genitalia is required for safe determination. The male genitalia are readily separated from those of related species (the terekholensis complex in the laminella species-group, see Remarks) by the knife-shaped valvae, a rectangular distal sclerotization of the gnathos, and a rectangular tergum VIII with characteristic posterolateral processes. The female genitalia are similar to those of several related species (see Nupponen 2007) but differ by the combination of details: elongate anterior corners of the sterigma; a rather broad sclerotized tip of the sterigma with a convex anterior margin; a widely concave posterior margin of sternum VII without flaps and sclerotized belts.

Description. Wingspan 9-10 mm. Head, collar, neck tuft, haustellum, scape and thorax brown with sparsely scattered paler scales. Labial palp: segment I creamy white; II and III brown mixed with pale beige. Legs: femur and hindleg tibia whitish beige, otherwise brown. Forewing nar-

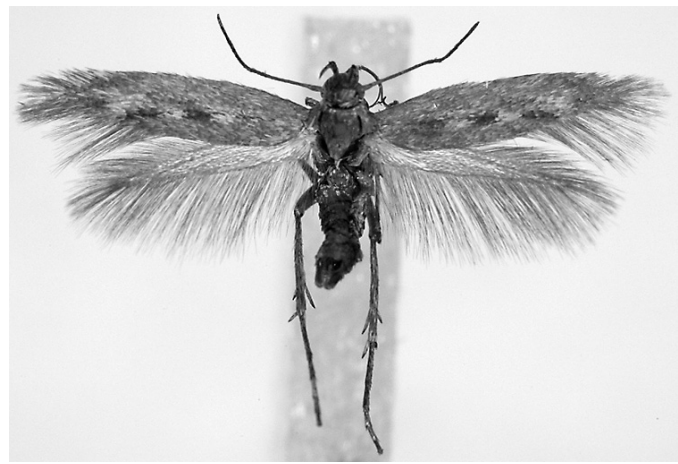

Fig. 1. Imago (male, holotype) of Scythris cultelloides Nupponen \& Sinev, sp. $\mathbf{n}$.

row, brown; in fold whitish brown scales forming a rather indistinct and distally broadened streak from base to cell end, cut by dark brown spots at $0.2,0.4$ and 0.6 ; indistinct dark brown spot subapically; scattered pale brown scales exist over the wing. Hindwing fuscous.

Male genitalia (Figs. 2-3). Asymmetrical. Uncus reduced. Gnathos asymmetrical, robust,

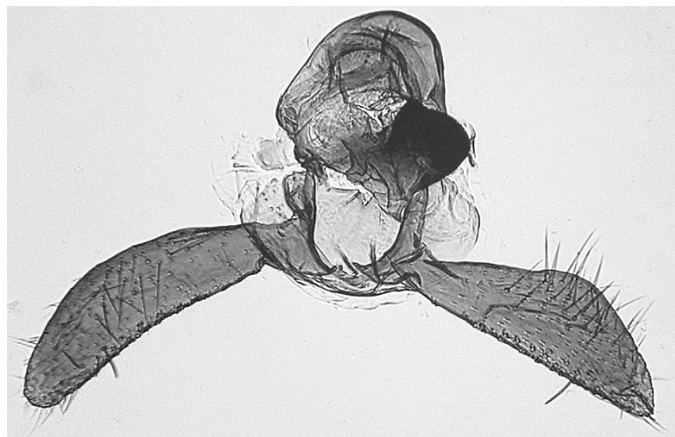

Fig. 2. Male genitalia of Scythris cultelloides Nupponen \& Sinev, sp. n. (paratype; GP 2/20.XI.2010 KN).

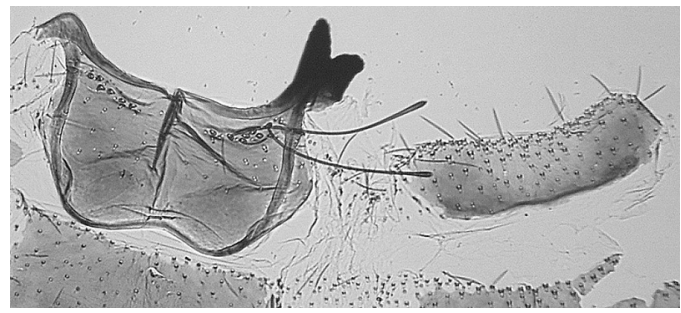

Fig. 3. Tergum VIII (left) and sternum VIII (right) of Scythris cultelloides Nupponen \& Sinev, sp. n. (paratype; GP 2/20.XI.2010 KN). 


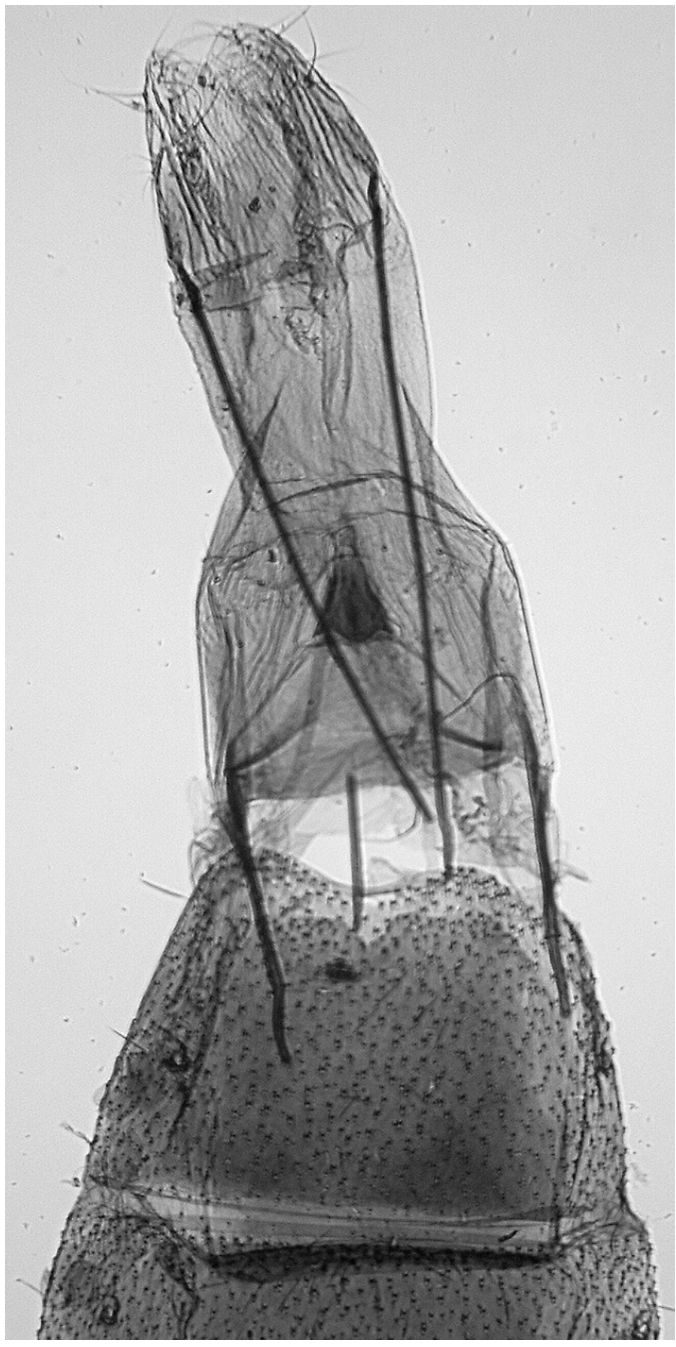

Fig. 4. Female genitalia of Scythris cultelloides Nupponen \& Sinev, sp. n. (paratype; GP 3/20.XI.2010 $\mathrm{KN})$.

curved posteriorly, basally wide; distally a large rectangular sclerotization. Tegumen asymmetrical, hood-shaped, left-weighted. Aedeagus short, bottle-shaped, posteriorly bent and elongated. Valvae slightly asymmetrical, long and narrow, knife-shaped; dorsal margin convex, ventral margin straight, tip rounded. Sternum VIII rectangular, four times wider than high. Tergum VIII rectangular, margins reinforced, anterior corners with small semicircular flaps; posterolaterally with robust asymmetrical processes, one cut off, the other distally strongly sclerotized and bifurcate.

Female genitalia (Figs. 4-5). Sterigma trian-

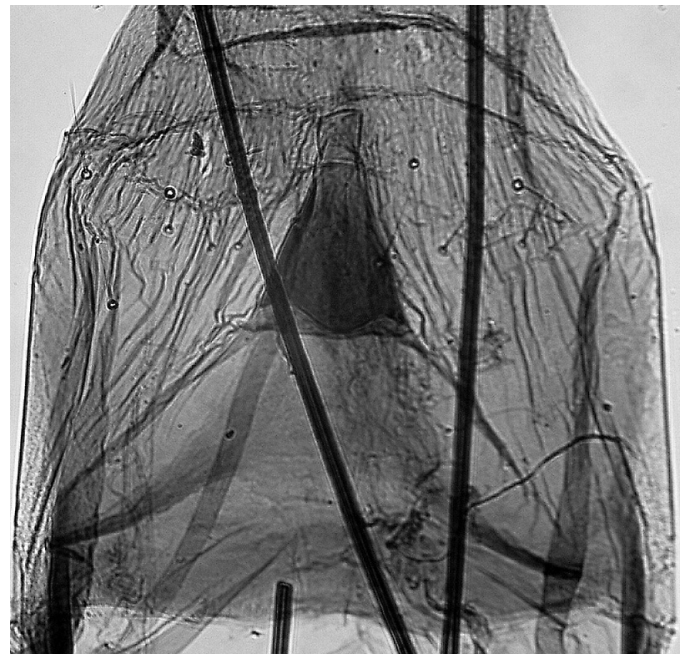

Fig. 5. Sterigma of Scythris cultelloides Nupponen \& Sinev, sp. n. (paratype; GP 3/20.XI.2010 KN).

gular, anterior corners elongate; posterior part strongly sclerotized, triangular, tip semitransparent, anterior margin medially convex. Sternum VII quadrangular, posterior margin concave without flap and sclerotized belt. Sternum VII quadrangular, with posteromedial incision. Apophyses anteriores $0.4 \times$ length of apophyses posteriores.

Bionomy. The species occurs at high altitudes $(2,500-3,000 \mathrm{~m})$ in late July and early August. The habitat is xerothermic steppe slopes with $\mathrm{Ar}$ temisia as a dominant plant. The moth is active at sunshine in the middle of the day.

Distribution. Kyrgyzstan (N Tien-Shan, Alai, Trans-Alai). The species is rather widely distributed in the mountain ranges of $\mathrm{C}$ and $\mathrm{S}$ Kyrgyzstan.

Etymology. Lat. cultellus $=$ a little knife. From shape of the valvae, being reminiscent of a knife.

Remark. S. cultelloides Nupponen \& Sinev, sp. $\mathbf{n}$. belongs to the terekholensis species-complex, comprising about 15 species in the Palaearctic region (see Nupponen 2003, 2007). These species are tentatively assigned to the heterogeneous laminella species-group. However, the relationship of the species in the terekholensis complex and the laminella species-group has not been confirmed by a phylogenetic analysis. The laminella group may be split into smaller species-groups in the future. 


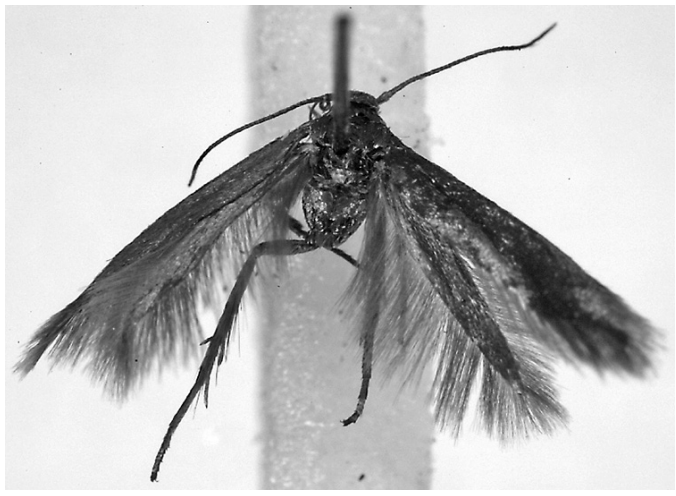

Fig. 6. Imago (male, holotype) of Scythris danilevskyi Nupponen \& Sinev, sp. $\mathbf{n}$.

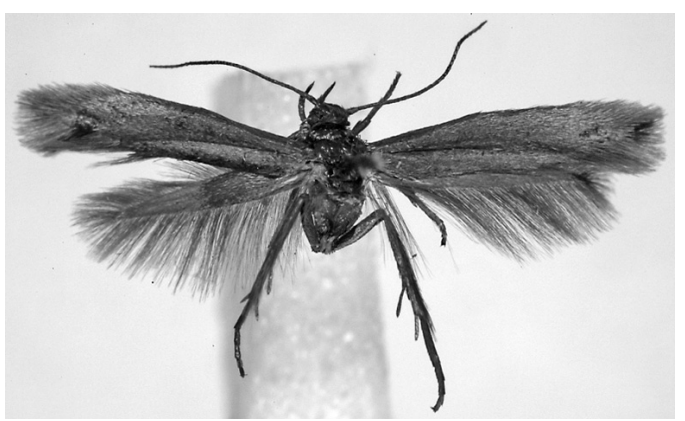

Fig. 7. Imago (male, paratype) of Scythris danilevskyi Nupponen \& Sinev, sp. $\mathbf{n}$.

\subsection{Scythris danilevskyi Nupponen \& Sinev, sp. n.}

Type material. Holotype: $\widehat{\jmath}$ (Fig. 6): Kazakhstan, Zailiskiy Alatau, M[alaja] Almaatinka, 2,500 m a.s.1., 22.VII.1957, A. S. Danilevsky \& V. I. Kuznetsov leg. Genitalia preparation preserved in glycerol. In coll. ZISP.

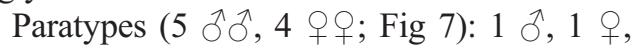
same data as holotype; 1 $\widehat{\jmath}$ Kazakhstan, Zailiskiy Alatau, M[alaja] Almaatinka, alpinskaja zona, 2,700 m a.s.1., 27.VII.1957, A. S. Danilevsky

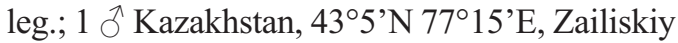
Alatau, Alma-Atinskij Nat[ure] P[ark], 1,9002,300 m a.s.1., Picea/meadow, 26.VII.1990, L.

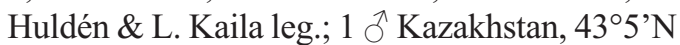
$77^{\circ} 15^{\prime} \mathrm{E}$, Zailiskiy Alatau, Alma-Atinskij Nat[ure] P[ark], 2,750 m a.s.1., meadow, 8.VII.1990, L. Kaila \& K. Mikkola leg.; 1 \% Kazakhstan, $43^{\circ} 5^{\prime} \mathrm{N} 77^{\circ} 15^{\prime} \mathrm{E}$, Zailiskiy Alatau, Alma-Atinskij Nat[ure] P[ark], 3,250 m a.s.l., alpine meadow, 6.VII.1990, L. Kaila \& K. Mikkola

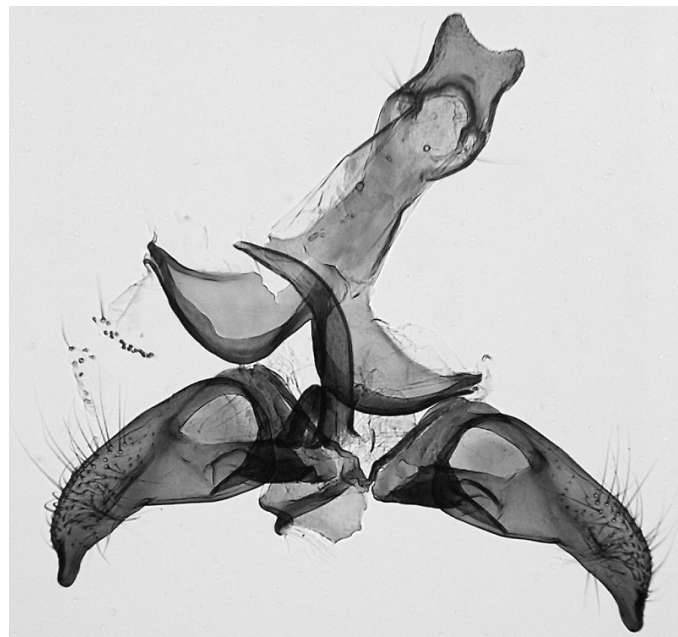

Fig. 8. Male genitalia of Scythris danilevskyi Nupponen \& Sinev, sp. n. (paratype; GP 1/13.I.2010 KN).

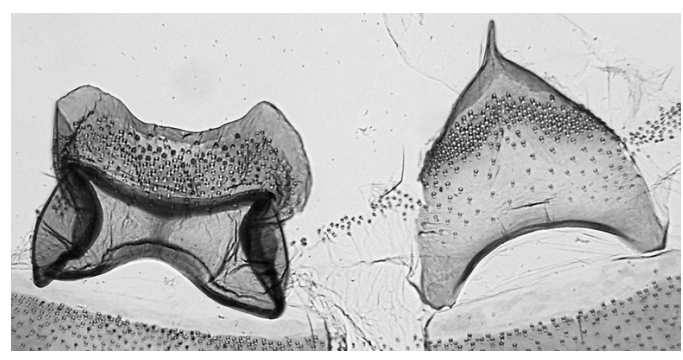

Fig. 9. Tergum VIII (right) and sternum VIII (left) of Scythris danilevskyi Nupponen \& Sinev, sp. n. (paratype; GP 1/13.I.2010 KN).

leg.; 1 đิ, 3 우 Kazakstan, Alma-Ata, 2,500 m a.s.1., 15.VII.1977, leg. \& coll. Eichler. Genitalia slides: K. Nupponen prep. no. 1/13.I.2010 ठิ, 2/13.I.2010 q; Jä[ckh] 9853 (ठ̊), 9842 (†), 9843 $(+)$. Two genitalia preparations preserved in glycerol. In colls. ZISP, MZH and Eichler.

Diagnosis. Externally S. danilevskyi Nupponen \& Sinev, sp. n. is easily confused with many small, dark scythridids. The male genitalia of $S$. danilevskyi resemble those of $S$. felixi Bengtsson $\&$ Sutter, 1995, but differ by a subquadrangular uncus, a medioposterior process at tergum VIII and shape of valvae. In the female genitalia, a small, cup-shaped sclerotization of the sterigma is a diagnostic character.

Description. Wingspan $10.5-11.5 \mathrm{~mm}$. Head, collar, neck tuft, haustellum, scape, labial palp, thorax and legs greenish bronzy; on haustellum, 


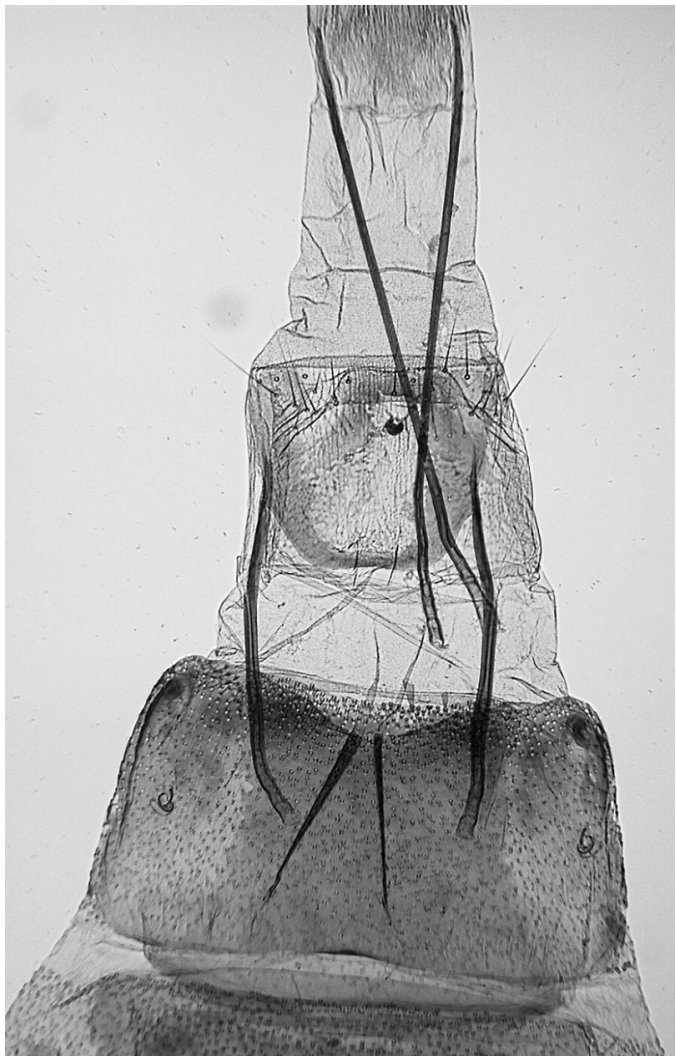

Fig. 10. Female genitalia of Scythris danilevskyi Nupponen \& Sinev, sp. n. (paratype; GP 2/13.I.2010 $\mathrm{KN})$.

labial palp and femur of legs scattered paler fuscous scales. Abdomen dark fuscous with greenish lustre. Forewing unicolorous greenish bronzy. Hindwing fuscous.

Male genitalia (Figs. 8-9). Uncus subquadrangular, margins concave, posterior corners slightly elongate. Gnathos a membrane. Basal part of tegumen two wide, in situ with parallel cup-shaped sclerotizations; distal portion long and narrow. Aedeagus slightly shorter than valva; base widened, basal $1 / 3$ straight, distal $2 / 3$ bent and distal third tapered. Valva thick and bent, basally swollen and basoventrally extended; basal half with a longitudinal medial ridge; distal portion bent inwards, shaped like a duck's head. Anterior part of sternum VIII subrectangular, laterally bent inwards, margins reinforced, anterior and posterior margins concave; posteriorly attached to a large subrectangular extension with concave posterior margin and convex lateral mar-

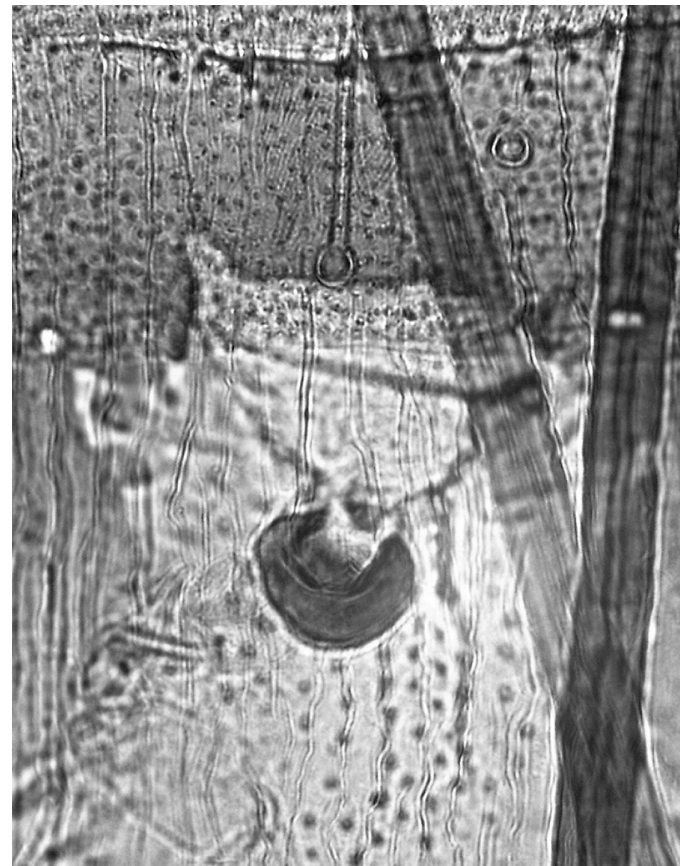

Fig. 11. Sterigma of Scythris danilevskyi Nupponen \& Sinev sp. n. (paratype; GP 2/13.I.2010 KN).

gins. Tergum VIII a pentagonal, posterolaterally folded, medioposteriorly a bent and pointed process; anterior margin concave and strongly sclerotized.

Female genitalia (Figs. 10-11). Sterigma a small, cup-shaped sclerotization, attached to a large subrectangular and medially membranous plate. Ostium situated medially near posterior margin of sterigma. Sternum VII rectangular, posterior margin incurved. Apophyses anteriores $0.6 \times$ length of apophyses posteriores.

Bionomy. The specimens have been found in July in different kinds of meadows at high altitude (2,500-2,750 m).

Distribution. Kazakhstan (Zailiskiy Alatau mountains).

Etymology. The species is dedicated to Dr. A. S. Danilevsky, a Russian entomologist and one of the collectors of the type series.

Remarks. S. danilevskyi Nupponen \& Sinev, sp. n. belongs to the heterogeneous laminella species-group. Its closest relatives are $S$. felixi and an undecribed species (K. Nupponen in prep.) from S Buryatia. See also Remarks of S. cultelloides above. 


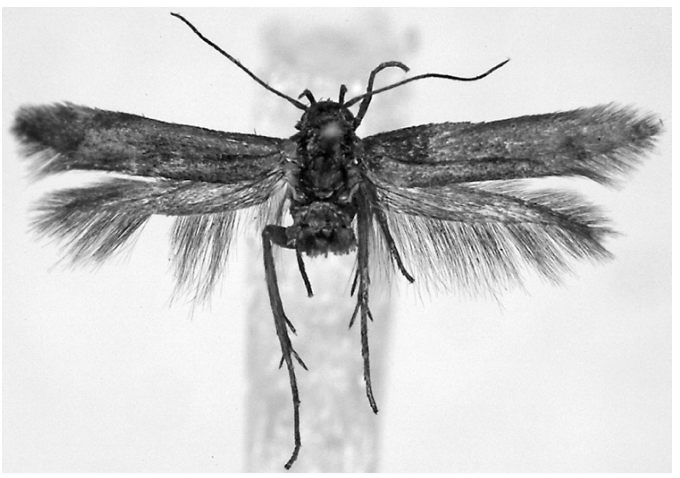

Fig. 12. Imago (male, holotype) of Scythris ganesha Nupponen \& Sinev, sp. $\mathbf{n}$.

\subsection{Scythris ganesha Nupponen \& Sinev, sp. n.}

Type material. Holotype: $\widehat{\jmath}$ (Fig. 12): Kyrgyzstan, 41 $26^{\circ} \mathrm{N} 76^{\circ} 29^{\prime} \mathrm{E}, 41 \mathrm{~km}$ E Naryn, 3,250 m a.s.1., alpine meadow, 5.VIII.1990, L. Huldén \& L. Kaila leg. Genitalia slide: K. Nupponen prep. no. 4/13.I.2010. In coll. MZH.

Diagnosis. S. ganesha Nupponen \& Sinev, sp. n. is difficult to separate from other small, dark scythridids by the external appearance. Narrow wings may help to identify the moth, but examination of the genitalia is required for safe determination. The male genitalia are very characteristic, with peculiar posterolateral processes of tegumen, leg-shaped valvae and shape of the uncus.

Description. Wingspan $9.5 \mathrm{~mm}$. Head, collar, neck tuft, scape and thorax dark brown, lustrous. Haustellum, legs and abdomen fuscous. Labial palp long, strongly upcurved; segment I dirty white, II and III dark brown with scattered whitish grey scales. Forewing narrow, dark brown with faint purplish lustre. Hindwing dark fuscous.

Male genitalia (Figs. 13-14). Uncus two parallel, large and sparsely setose processes; at base a furrowed bulge; basal part large and hollow, distal portion bent inwards, resembling head of Bittern. Gnathos base a wide hood; posterior prong short, tapered and pointed. Tegumen basally wide, slightly tapered towards posterior part; posterolaterally on each side two long and robust, digitate and distally spinose processes. Aedeagus short and very thick, straight, distally tapered. Valva long, leg-shaped; basally wide, angled in-

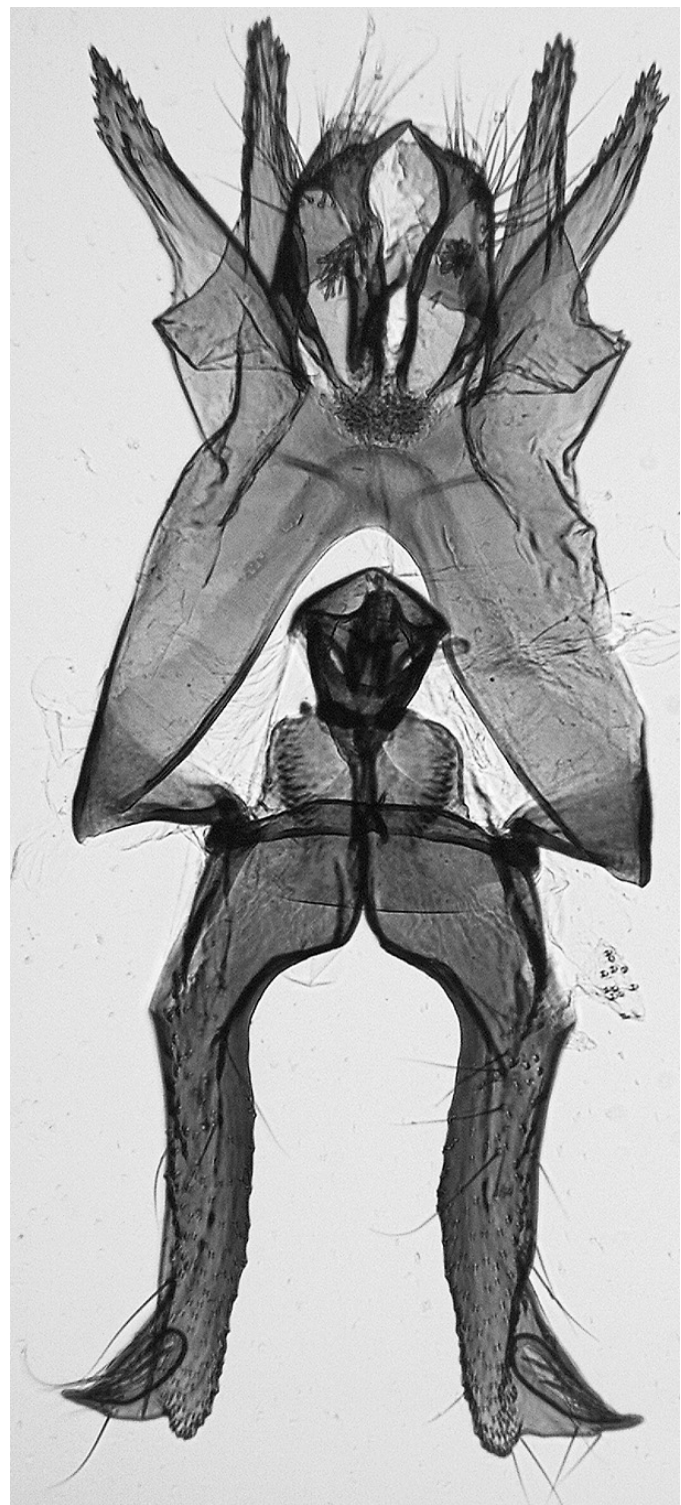

Fig. 13. Male genitalia of Scythris ganesha Nupponen \& Sinev, sp. n. (holotype; GP 4/13.I.2010 KN).

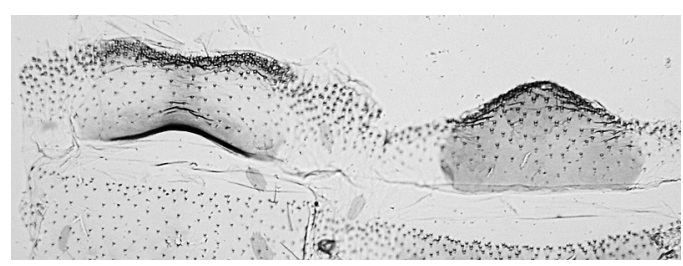

Fig. 14. Tergum VIII (left) and sternum VIII (right) of Scythris ganesha Nupponen \& Sinev, sp. n. (holotype; GP 4/13.I.2010 KN). 


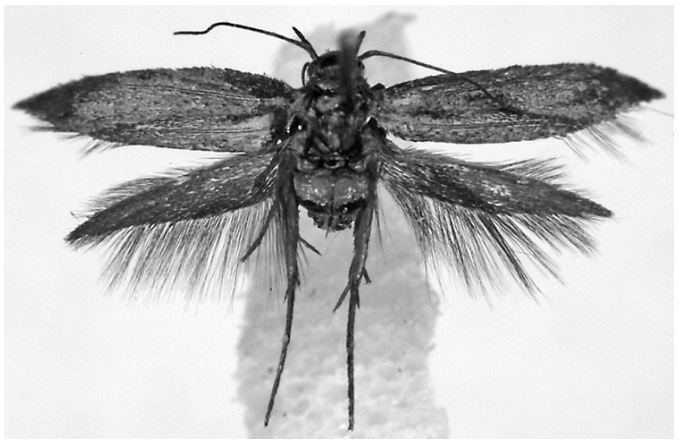

Fig. 15. Imago (female) of Scythris sp. Kyrgyzstan, N Tien-Shan.

wards at $1 / 3$; distal $2 / 3$ straight, subapically with a triangular process having elongated tip and an oval sclerotization medially; valvae basally attached to sclerotized transverse band and two furrowed plum-like extensions. Sternum VIII a pentagonal plate. Tergum VIII rectangular, twice wider than high; anterior margin reinforced and incurved, posterior margin slightly concave.

Female genitalia. Unknown.

Bionomy. The holotype was found in early August. The habitat is an alpine meadow at high altitude.

Distribution. Kyrgyzstan (N Tien-Shan). Only known from the type locality.

Etymology. The species name allude to the shape of the male genitalia of the species, being reminiscent of Ganesha, a Hindu God of success having a human body with four hands and elephant's head.

Remarks. S. ganesha Nupponen \& Sinev, sp. n. cannot be assigned to any known speciesgroup.

\subsection{Scythris sp.}

Material. 1 (Fig. 15): Kyrgyzstan, $41^{\circ} 26^{\prime} \mathrm{N}$ 76²9'E, $40 \mathrm{~km}$ E Naryn, 2,750 m a.s.l., grazed steppe, 2.VIII.1990, L. Kaila \& K. Mikkola leg. Genitalia slide: K. Nupponen prep. no. 5/13.I .2010. In coll. MZH.

External appearance. Wingspan $10 \mathrm{~mm}$. The specimen is very worn. Forewings are dark brown, with blackish brown scales around fold. Hindwings are dark fuscous, and underside is almost covered by blackish brown.

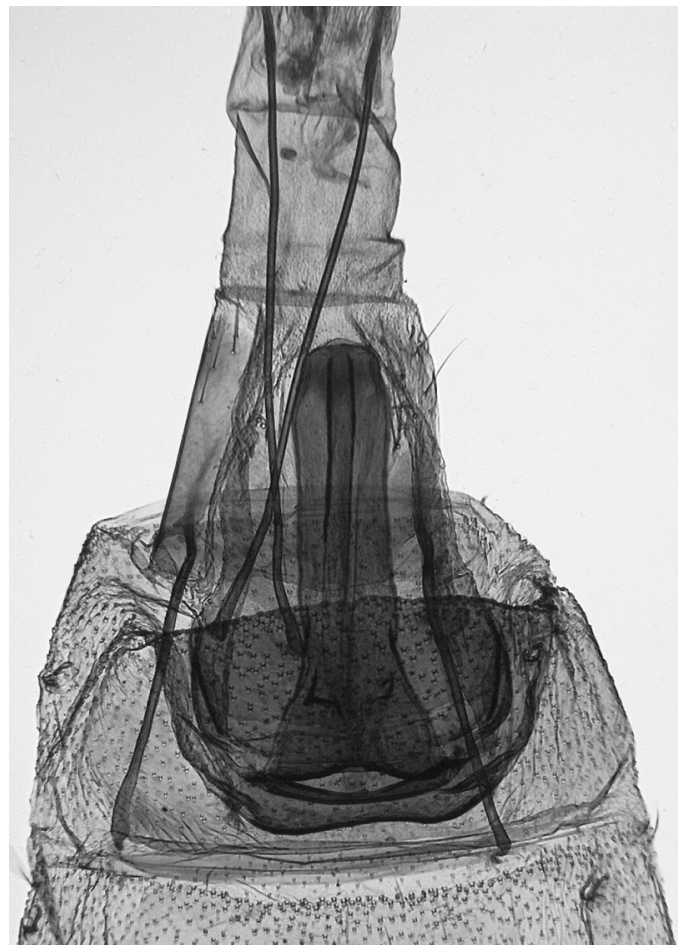

Fig. 16. Female genitalia of Scythris sp. (Kyrgyzstan, N Tien-Shan; GP 5/13.I.2010 KN).

Female genitalia (Fig. 16). Sterigma digitate, long and robust, strongly scerotized, basally widened and attached to a large elongate, anterolaterally folded and anteriorly reinforced plate. Sternum VII rectangular, twice wider than high. Apophyses anteriores half length of apophyses posteriores.

Bionomy. The habitat is grazed steppe at high altitude $(2,750 \mathrm{~m})$.

Remarks. A single female that is impossible to assign to any known species, neither by the external appearance nor by the characters in the genitalia. Further material, including males, is needed until the taxon can be determined at species level.

Acknowledgements. Our thanks are due to Dr. Lauri Kaila (MZH, Helsinki) for letting us examine the material preserved in MZH; to Mr. Bengt $\AA$. Bengtsson (Färjestaden, Sweden) for information of the specimens of S. danilevskyi in coll. Eichler; to Mr. Kimmo Silvonen (Espoo, Finland) for help in processing the photographs; to Elena Nupponen (Espoo, Finland), Timo Nupponen (Espoo, Finland) and Faunatica $\mathrm{Oy}$ for various kinds of support and assistance. Bengt Bengtsson and an anonymous referee kindly improved the manuscript. 


\section{References}

Bengtsson, B. Å. 1997: Notes on interesting scythridids in the Zoological Museum, Helsinki, Finland (Lepidoptera, Scythrididae). - Entomologica Fennica 8: 89102.

Nupponen, K. 2003: Contribution to the scythridid fauna of southern Buryatia, with description of seven new species (Lepidoptera: Scythrididae). — Entomologica Fennica 14: 25-45.
Nupponen, K., Jürivete, U. \& Pototski, A. 2005: Records of scythridids from Southeastern Kazakhstan, with description of five new species (Lepidoptera: Scythrididae). - Entomologica Fennica 16: 65-73.

Nupponen, K. 2007: Notes on the Scythrididae fauna of the Volgo-Ural region and southern Buryatia, with one new synonym and descriptions of six new species. SHILAP Revista de Lepidopterologia 35: 231-249. 